\title{
PENINGKATAN KUALITAS BELAJAR SISWA SEKOLAH DASAR MELALUI FASILITASI KELENGKAPAN SUMBER BELAJAR DAN PENDAMPINGAN DI KEC. MOJO KAB.KEDIRI
}

\author{
Hendra Kusuma ${ }^{1}$ \\ Fakultas Ekonomi dan Bisnis, Universitas Muhammadiyah Malang ${ }^{l}$
}

\begin{abstract}
Abstrak
Pemerataan akses sumber belajar menjadi sebuah kewajiban bagi setiap warga negara Indonesia untuk meningkatkan kualitas sumber daya manusia. Siswa Sekolah Dasar membutuhkan alat kelangkapan belajar seperti buku, peraga dan pendamping belajar. Kecmatan Mojo Kabupaten Kediri terletak di sebelah selatan Kota Kediri yang secara umum masyarakat di daerah tersebut memiliki keterbatasan terhadap akses penunjang belajar selain sekolah. Dengan menyediakan sarana belajar seperti tempat belajar, pendamping belajar, buku, alat peraga diharapkan dapat meningkatkan kualitas sumber daya manusia terutama bagi siswa sekolah dasar tersebut
\end{abstract}

Kata kunci: Kualitas belajar, sumber belajar, pendampingan

\section{Pendahuluan}

Pemerataan pendidikan menjadi dasar utama dalam meningkatkan kualitas sumber daya manusia. Di Jawa timur akses terhadap pendidikan dapat dinyatakan lebih baik dari pada provinsi yang lainnya. Namun tidak semua masyarkat di Provinsi Jawa Timur yang dapat merasakan kualitas pendidikan yang merata. Bagi mereka yang mempunyai kemampuan keuangan diatas rata-rata akan mendapatkan kualitas dan fasilitas pendidikan yang sangat baik. Sedangkan masyarakat yang hidup di bawah garis kemiskinan mendapatkan fasilitas standart yang telah diberikan oleh pemerintah.

Penambahan jumlah jam belajar untuk meningkatkan kemampuan akademik siswa pada umumnya di dapatkan dengan cara mengeluarkan biaya tertentu. Hal tersebut yang tidak dapat diakses oleh setiap lapisan masyarakat khususnya yang hidup di bawah garis kemiskinan. Penngkatan kualitas pendidikan diharapkan mampu meningkatkan kualitas hidup. Pendidikan juga merupakan sebuah investasi jangka panjang dimana investasi di bidang sumberdaya manusia yang dikorbankan adalah sejumlah dana yang dikeluarkan dan kesempatan memperoleh penghasilan selama proses investasi. Yang diperoleh sebagai imbalannya adalah tingkat penghasilan yang lebih tinggi untuk mampu mencapai tingkat konsumsi yang lebih tinggi pula. Investasi yang kemudian dinamakan Human Capital (Simanjuntak, 1985). Penerapannya dapat dilakukan dalam hal: pendidikan dan latihan, migrasi, perbaikan gizi dan kesehatan

Pendidikan dan latihan merupakan salah satu faktor yang penting dalam pengembangan sumberdaya manusia. Pendidikan dan latihan tidak saja menambah pengetahuan, akan tetapi juga meningkatkan keterampilan bekerja, dengan demikian meningkatkan produktivitas kerja.

Pendidikan dan latihan dipandang sebagai investasi yang imbalannya dapat diperoleh beberapa tahun kemudian dalam bentuk pertambahan hasil kerja. Asumsi dasar teori Human Capital adalah bahwa seseorang dapat meningkatkan melalui peningkatan pendidikan. Berarti setiap penambahan satu tahun sekolah, disatu pihak meningkatkan kemampuan kerja dan tingkat penghasilan seseorang, akan tetapi di pihak lain menunda penerimaan penghasilan selama satu tahun dalam mengikuti sekolah tersebut.

Metode pendidikan dan fasilitas merupakan faktor penting dalam meningkatkan ketertarikan masyarakat dalam meningkatkan kualitas sumber daya manusia. Belajar berkelompok adalah salah satu dari sekian

\footnotetext{
${ }^{1}$ hendrakusuma@umm.ac.id
} 
banyak metode yang dipandang dapat meningkatkan kualitas belajar. Ketersediaan sarana dan prasarana seperti bahan bacaan, akses informasi, tempat yang representatif dapat meningkatkan ketertatikan dalam belajar.

Kegiatan belajar dalam rangka meningkatkan kualitas sumber daya manusia tidak hanya dilakukan oleh orang dewasa. Kegiatan, metode dan sarana belajar bagi anak-anak penting untuk difasilitasi dengan tujuan memberikan dasar yang baik dan berkualitas bagi peningkatan kualitas sumber daya manusia. Bentuk dari fasilitasi kegiatan belajar bagi anak-anak salah satunya adalah perpustakaan yang menyediakan beragam sumber bacaan yang memiliki kandungan keilmuan dan pengetahuan sesuai dengan kebutuhan. Pentingnya fasilitas pendidikan seperti perpustakaan menjadi dasar utama dalam peningkatan sumber daya manusia. Fasilitas perputakaan, alat tulis dan pendampingan dalam kelompok belajar ditujukan kepada siswa Sekolah Dasar di daerah Kecamatan Mojo Kabupaten Kediri. Hal tersebut dilatar belakangi karena semangat belajar siswa Sekolah Dasar di wilayah tersebut masih rendah. Rendahnya minat belajar diakibatkan salah satunya oleh fasilitas yang tidak mendukung.

\section{MATERI DAN METODE PELAKSANAAN}

Hasil yang dicapai dari kegiatan pengabdian ini adalah peningkatan kualitas sumber daya manusia dari fasilitasi sarana dan sumber belajar bagi anak-anak siswa sekolah dasar di kecamatan Mojo Kabupaten Kediri. Fasilitas yang dimaksud adalah penyediaan tempat belajar kelompok dan perpustakaan, sedangkan dampak dan manfaat yang diperoleh masyarakat Kec. Mojo Kabupaten Kediri adalah 1) ruang belajar bersama 2)perpustakaan dan bahan baca bagi abak-anak sekolah dasar.

\section{Kerangka Pemecahan Masalah}

Permasalahan dari program peningkatan kualitas sumber daya manusia melalui pembentukan kelompok belajar dan perpustkaan mandiri bagi anak di Kec. Mojo Kab. Kediri adalah tempat. Untuk mengatasi permaslahan pertama yaitu tempat sebagai sarana belajar kelompok, maka disewakan satu ruang milik salah satu tokoh masyarakat di Kec.Mojo yaitu H.Sodiq Tohari yang juga berperan sebagai pendamping belajar anak-anak di bidang keagamaan sedangkan untuk dibidang akademik akan dicarikan guru pendamping. Permasalahan yang kedua adalah ketersediaan bahan buku sebagai perpustakaan sederhana. Untuk mengatasi hal tersebut maka pengadaan buku dan kerjasama dengan perpustakaan setempat dirasa perlu untuk direalisasikan.

\section{Khalayak Sasaran}

Program kegiatan ini ditujukan untuk masyarakat Dsn.Bangsongan Kec. Mojo Kabupaten Kediri. Alasan pemilihan lokasi tersebut karena terindikasi telah terjadi degradasi kualitas sumber daya manusia dan keagamaan sehingga dipandang penting untuk hadir di tengah-tengah masyarakat untuk memfasilitasi dan meningkatkan kualitas sumber daya manusia.

\section{Metode Kegiatan}

Bentuk dari pengabdian ini adalah pembentukan kelompok belajar dan inisiasi perpustakaan sebagai sarana belajar, maka metode kegiatan yang dilakukan adalaha 1) pembentukan kelompok belajar 2) pembuatan / inisiasi perpustakaan. Secara umum ketersediaan sarana belajar diluar sekolah merupakan hal penting yang dapat meningkatkan kualitas sumber daya manusia. Anak-anak merupakan generasi penerus yang harus ditingkatkan kualitas akademik dan keagamaannya. Untuk mewujudkan program tersebut maka berikut adalah langkah-langkah yang diambil dan keterlibatan mitra dalam program pengabdian.

Tabel 1 langkah dan solusi dala peningkatan sumber daya manusia

\begin{tabular}{|l|l|l|l|}
\hline No & Permasalahan & Solusi & $\begin{array}{l}\text { Keterlibatan } \\
\text { mitra }\end{array}$ \\
\hline 1 & $\begin{array}{l}\text { Fasilitas } \\
\text { belajar }\end{array}$ & $\begin{array}{l}\text { Menyediakan } \\
\text { fasilitas tempat } \\
\text { belajar }\end{array}$ & $\begin{array}{l}\text { Menyediakan } \\
\text { ruang belajar }\end{array}$ \\
\hline 2 & $\begin{array}{l}\text { Guru } \\
\text { pendamping }\end{array}$ & $\begin{array}{l}\text { Menyediakan guru } \\
\text { pendamping } \\
\text { akademik dan } \\
\text { keagamaan }\end{array}$ & $\begin{array}{l}\text { Menjadi } \\
\text { pendamping / } \\
\text { guru } \\
\text { keagamaan }\end{array}$ \\
\hline 3 & $\begin{array}{l}\text { Bahan ajar } \\
\text { dan buku } \\
\text { bacaan }\end{array}$ & $\begin{array}{l}\text { Menyediakan } \\
\text { sumber belajar yaitu } \\
\text { buku dan fasilitas } \\
\text { pendukung }\end{array}$ & $\begin{array}{l}\text { Menyediakan } \\
\text { tempat buku }\end{array}$ \\
\hline
\end{tabular}




\section{HASIL DAN PEMBAHASAN}

Kegiatan belajar dan mengajar tidak terlepas dari sarana belajar dan sumber belajar. Selain itu ketersediaan pengajar yang kompeten dibidangnya dapat meningkatkan hail yang ingin dicapai. Jika dilihat dari fasilitas yang dimiliki di Kecamatan Mojo sebagai tempat pengabdian, maka dapat dinyatakan cukup memadai. yang dimaksud memadai adalah tersedianya fasilitas pendidikan ulai dari TK, SD/MI, SMP/MTs, SMU/SMA/MA hingga pesantren.

Secara keseluruhan di Kecamatan Mojo sendiri terdapat 30 Sekolah Dasar yang tersebar pada 20 Desa, sedangkan untuk SMP terdapat 2 SMP Negeri. Perkembangan jumlah dan fasilitas pendidikan keagamaan di Kecamatan Mojo hampir seimbang dengan pendidikan umum. Di dalam data yang di himpun dari Badan Pusat Statistik menyebutkan bahwa jumlah Pondok Pesantren di Kecamatan Mojo sebanyak 23, dimana yang terbanyak terletak di Desa Kraton sebanyak 10 pondok pesantren dan yang kedua adalah desa Ploso sebanyak 9 pondok pesantren.

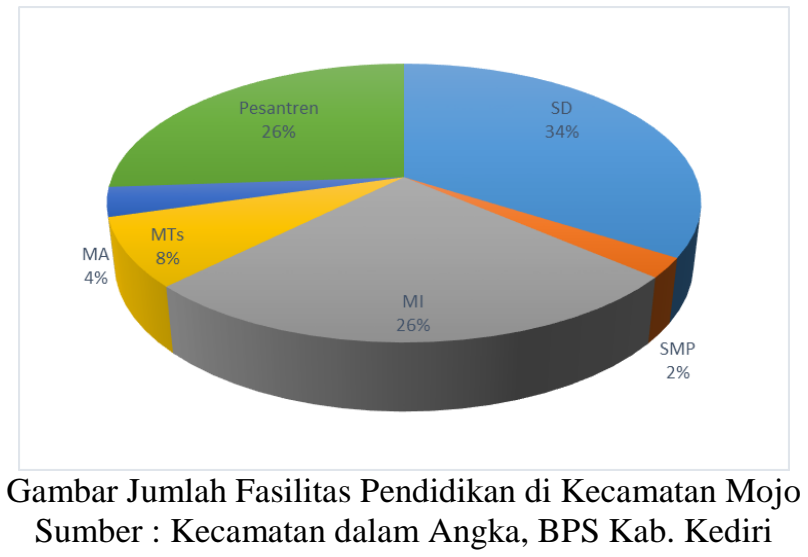

Dalam program pengabdian ini diangkat permasalahan mengenai peningkatan kualitas sumber daya manusia melalui pembentukan kelompok belajar dan perpustkaan mandiri. Adapun solusi yang ditawarkan untuk mengatasi masalah tersebut adalah :

\section{Fasilitas belajar}

Berdasarkaan definisi dari fasilitas merupakan segala sesuatu yang dapat memudahkan upaya dan memperlancar kerja dalam rangka mencapai suatu tujuan (Arianto, 2013). Sehingga fasilitas belajar dapat didefinisikan sebagai semua kebutuhan yang diperlukan oleh peserta didik dalam rangka untuk memudahkan, melancarkan dan menunjang dalam kegiatan belajar di sekolah maupun di rumah.

Untuk menunjang tercapainya tujuan yaitu dapat memudahkan, melancarkan serta menunjang kegiatan belajar, maka dibutuhkan sarana belajar. Definisi Sarana belajar menurut (Nur, 2009) adalah peralatan dan perlengkapan yang secara langsung dipergunakan dan menunjang proses pendididikan, khususnya proses belajar mengajar, seperti gedung, ruang kelas, meja kursi, serta alat-alat dan media pengajaran.

Pada program pengabdian ini fasilitas belajar untuk ruang atau tempat belajar seperti yang direncanakan disediakan oleh mitra yaitu bertempat di tempat ibadah yang didirikan oleh H.Sodiq Tohari. Fasilitas belajar lain yang disediakan guna membantu terselenggaranya tempat belajar yaitu Meja sebanyak 2 buah dan Almari buku 1 buah.

\section{Bahan ajar dan buku bacaan}

Buku dan bahan ajar merupakan salah satu hal penting dalam berjalannya proses belajar dan mengajar. (Bangun, 2008) menyatakan bahwa lengkap dan tidaknya peralatan belajar, baik yang dimiliki sekolah, dapat menimbulkan hasil akibat tertentu terhadap prestasi belajar murid, kekurangan peralatan belajar dapat membawa akibat yang negatif antara lain misalnya murid tidak bisa belajar secara baik, sehingga sulitlah diharapkan untuk mencapai prestasi yang tinggi.

Tabel Realisasi Fasilitas Belajar

\begin{tabular}{|l|l|l|}
\hline No & Jenis Barang & Jumlah \\
\hline 1 & Meja belajar & 2 \\
\hline 2 & Almari & 1 \\
\hline 3 & rak buku & 1 \\
\hline 4 & buku gambar & 3 lusin \\
\hline 5 & alat tulis & 10 set \\
\hline 6 & buku cerita & 50 judul \\
\hline
\end{tabular}




\section{Pendampingan belajar}

Salah satu fasilitas belajar selain dari melengkapi sumber belajar adalah penyediaan pendamping dalam belajar. Pada umumnya kegiatan belajar yang disertai dengan guru pendamping disebut sebagai kegiatan Les. Penduduk di sekitar wilayah Mojo memiliki akses yang terbatasa atas kegiatan belajar tambahan. Hal tersebut dikarenakan selain mahalnya biaya yang harus dikeluarkan untuk belajar tambahan juga karena ketersediaan tempat belajar.

\section{KESIMPULAN}

Peningkatan kualitas pendidikan tidak hanya dapat dilakukan melalui fasilitas belajar saja, namun keberadaaan pendamping atau guru sangat diperlukan dalam meningkatkan kualitas belajar. Fasilitas belajar yang telah disediakan meliputi alat tulis, meja belajar, rak buku, buku cerita. Sedangkan pendamping belajar akan disediakan pada tahap berikutnya

\section{UCAPAN TERIMAKASIH}

Kegiatan pengabdian ini dapat terselenggara atas pendanaan yang diberikan oleh Universitas Muhammadiyah Malang melali dana Block Grant Fakultas Ekonomi dan Bisnis.

\section{REFERENSI}

Alonse, Abel Duarte,2011," Muscadines, wineries and Value added products: an exploratory study", British Journal, vol 113, no3

Suparmoko(1999:47) Ekonomi Sumber Daya Alam dan Lingkungan, edisi 2, BPFE UGM Studi Kelayakan....

Sumodiningrat,G, 1997,'Pembangunan Daerah dan Pemberdayaan Masyarakat”Bina Rena Pariwara Jakarta

Sumodiningrat, G, 1999"Pemberdayaan masyarakat dan Jaring Pengaman Sosial" Gramedia Jakarta

Suparmoko, 1999, Ekonomi Sumber Daya Alam dan Lingkungan, edisi 2, BPFE

Yahya \&Goh,2002, Managing human resources toward achieving knowledge management. Journal of Knowledge Management. 6(5). 457-468. 